Tropical Journal of Pharmaceutical Research, February 2010; 9 (1): 19-26

(C) Pharmacotherapy Group,

Faculty of Pharmacy, University of Benin

Benin City, 300001 Nigeria.

All rights reserved.

Research Article

Available online at http://www.tjpr.org

\title{
Study of the Molecular Mechanism of Anti-inflamma- tory Activity of Bee venom in Lipopolysaccharide Stimulated RAW 264.7 Macrophages
}

\section{Pham Duy Lam ${ }^{1}$, Prabhat Kumar Mandal ${ }^{2}$, Seung Yang Hak ${ }^{3}$ and Seong-Gu Hwang ${ }^{1^{*}}$}

${ }^{1}$ Division of Animal Life \& Environmental Science. College of Agriculture and Life Science, Hankyong National University, Anseong-si, Gyonggi-do, S. Korea-456 749, ${ }^{2}$ Department of Food Science and Biotechnology of Animal Resources, Konkuk University, Seoul, S. Korea-143 701, ${ }^{3}$ National Institute of Animal Science, Rural Development Administration, Cheonan, S. Korea, 330-801

\begin{abstract}
Purpose: Bee venom $(B V)$ is traditionally used in many inflammatory chronic conditions but its mechanism of action at molecular level is not fully understood. This study was undertaken to elucidate the mechanism of action of bee venom at the molecular level

Methods: We used lipopolysaccharide (LPS) stimulation in Raw 264.7 macrophage (RM) cells and studied the effect of BV on cell proliferation, inflammation related protein expression by western blotting and RNA expression by reverse transcriptase polymerase chain reaction (RT-PCR).

Results: Bee venom was toxic to RM cells above10 $\mu \mathrm{g} / \mathrm{ml}$ but reduced the production of nitric oxide (NO) at $2-10 \mu \mathrm{g} / \mathrm{ml}$ in LPS stimulated RM cells by inhibiting the expression of inducible nitric oxide synthase (iNOS) and cyclooxigenase (COX)-2 via nuclear factor (NF)-kB. However, bee venom also induced the pro-inflammatory cytokine, interleukin (IL)-1 $\beta$ via p38 mitogen activated protein kinase (MAPK) which is known to stimulate inflammatory activity.

Conclusion: It seems that NFKB and p38 MAPK signal pathways are involved in triggering the functional activation of LPS-stimulated macrophage. We suggest that some components of bee venom can cause inflammation by inducing IL-1 $\beta$ via p38 MAPK while others act as anti-inflammatory by suppressing iNOS and COX2 via NFKB.
\end{abstract}

Keywords: Bee venom, Cyclooxygenase-2, Interleukin 1beta, Inducible nitric oxide synthase, Lipopolysaccharide, Macrophage, Mitogen activated protein kinase, Nuclear factor kappa-B. 


\section{INTRODUCTION}

Bee venom (BV) from the sting of Honeybee (Apis mellifera) is traditionally used in China Korea, Japan for arthritis, tendinitis, bursitis and other chronic conditions. It is reported to have proinflammatory [1] and antiinflammatory effects [2-6]. Several studies have reported that following subcutaneous injection of a solution of $\mathrm{BV}$ into rat paw, as an experimentally-produced honeybee's sting effect, the animal showed unique expressions of persistent nociception and inflammation [79]. Since the first report of anti-inflammatory effect of BV [10], many studies using diverse methodologies have supported this finding.

BV contains various peptides, including mellitin, apamin, adolapin and enzymes as well as non-peptide components such as histamine, lipid, carbohydrates [11-13]. Excessive production of nitric oxide (NO) and prostaglandin (PGE) play an important role in various inflammatory diseases [14]. In inflammatory reactions, NO is generated from arginine, mainly by inducible nitric oxide synthase (iNOS) while PGE is generated from arachidonic acid mostly by cyclooxygenase (COX-2). Recent studies have demonstrated that eukaryotic transcription factor nuclear factor-kappa B (NF-kB) is involved in the regulation of COX2 and iNOS expression [15]. Accordingly, many substances developed to date to prevent inflammatory damage either by suppressing the activation of iNOS or COX-2 directly, or by inhibiting NFKB signalling, which regulates them in the transcriptional stage [16].

The biological functions of NFKB are involved in many pro-inflammatory cytokines such as TNF- $\alpha$, TNF- $\beta$, IL-1 $\beta$, IL-6 and IL-8 [17]. TNF$\alpha$ plays a key role in the induction and maintenance of inflammation due to autoimmune reactions, by activating $T$ cells and macrophages and by up-regulating other pro-inflammatory cytokines [18]. Likewise, IL-1 $\beta$, one of the most important inflammatory cytokines secreted by macrophages, is induced by LPS. During inflammation, increased release of $\mathrm{IL}-1 \beta$ leads to cell or tissue damage [19] and thus, reduction in IL$1 \beta$ released from macrophages may retard inflammatory responses to LPS stimulation. Mitogen-activated protein kinase (MAPK) pathway, one of the most extensively studied intracellular signaling cascades, is also seems to have pro-inflammatory responses $[20,21]$

It appears from the reported studies that bee venom has both pro-inflammatory and antiinflammatory effects; however, the mechanisms underlying these events at cellular level are not fully understood. Therefore, in the present study, we investigated the effect of BV on NO generation and the expression of iNOS, COX-2, NF-KB and P38 MAPK, IL-1 $\beta$, TNF- $\alpha$ in RM cells stimulated by LPS in order to identify elements affecting anti-inflammatory \& pro-inflammatory action in RM cells.

\section{EXPERIMENTAL}

\section{Chemicals}

Bee venom (99.5\% purity) was supplied by Chung-Jin Biotech Co. Ltd, Korea. Anti-iNOS, COX-2, IL-1 $\beta$, TNF- $\alpha$, NFkB, p38MAPK antibody and HRP were purchased from Santa Cruz Biotechnology Inc, Santa Crutz, CA, USA. The primers (see Table 1) were synthesised by Bioneer Corporation, Korea. Alamar blue was received from Invitrogen, USA while RAW 264.7 murine macophages were obtained from American Type Culture Collection, Rockville, MD, USA.

\section{Experimental plan}

We studied the effect of BV at different doses in the LPS stimulated RM cells by measuring NO production and the expression of different inflammatory enzymes and cytokines at protein level by Western blotting and at mRNA levels by RT-PCR in order to understand the mode of action of bee venom on inflammatory pathway. 


\section{Preparation of bee venom solution}

Dried $0.01 \mathrm{~g}$ bee venom was diluted with 10 $\mathrm{ml}$ Dalbeco's modified eagle's medium (DMEM) medium (10\% foetal bovine serum (FBS), $1 \%$ penicillin) to make $1000 \mu \mathrm{g} / \mathrm{ml}$, and then filtered. The solution was further diluted to $0.5,1,2,5$, and $10 \mu \mathrm{g} / \mathrm{ml}$ before actual use.

\section{Culture of Raw 264.7 cells and sample treatment}

Mouse macrophage cell line Raw 264.7 cells were cultured in (DMEM) with $10 \%$ faetal bovine serum and $1 \%$ penicillin in a humidified atmosphere of $5 \% \mathrm{CO}_{2}$ at $37{ }^{\circ} \mathrm{C}$. The cells were stimulated with LPS $(1 \mu \mathrm{g} /$ well $) ; 1 \mathrm{~h}$ later, they were treated with $0,0.5,1,2,5$ and $10 \mu \mathrm{g} / \mathrm{ml}$ of BV and cultured for $24 \mathrm{~h}$ Various analyses were carried out on them as described in the following sections.

\section{Cell proliferation assay}

To determine the effect of BV on cell proliferation, the cells were incubated for $24 \mathrm{~h}$ with BV at different concentrations $(0,0.5,1,2$, $5,10,20 \mu \mathrm{g} / \mathrm{ml})$. Cell proliferation was measured by alamar blue (AB) assay. A single plate was used for each assay and all measurements were conducted on a microplate reader (UVmax, Molecular Devices). In the assay, $10 \mu \mathrm{l} A B$ reagent (Serotec) was added to each well, and after 3 $\mathrm{h}$ of incubation at $37{ }^{\circ} \mathrm{C}$ under $5 \% \mathrm{CO} 2$ in a humidified atmosphere, the absorbance difference was determined at 570nm using a spectrophotometer (Tecan Sunrise ${ }^{\mathrm{TM}}$ Absorbance Reader). The cell proliferation was calculated by comparing with control and expressed in percent.

\section{Nitric oxide assay}

To examine the effects of BV on NO production, we measured the levels of nitrite (an index of NO formation) produced by LPS. Thereafter, NO production assay was used to confirm the results. The RAW 264.7 cells were transferred to a 96-well plate (1000 cells/well) and incubated overnight. The cells were stimulated with LPS $(1 \mu \mathrm{g} /$ well $)$, and $1 \mathrm{~h}$ later, they were treated with $0,0.5,1,2,5$ and $10 \mu \mathrm{g} / \mathrm{ml}$ of BV and cultured for $24 \mathrm{~h}$. One hundred microlitres of the culture supernatants were transferred into another 96-well plate and treated with $100 \mu \mathrm{l}$ of Greiss reagent solution. After waiting for reaction to take place at room temperature, light absorption was measured at $570 \mathrm{~nm}$ with a spectrophotometer (Tecan Sunrise ${ }^{\mathrm{TM}}$ Absorbance Reader). NO was assessed with the aid of a standard curve prepared with standard sodium nitrite solutions $(0,3.75,7.5$, $15,30,60,120$ and $240 \mu \mathrm{M})$.

\section{Protein assay}

Cellular proteins were extracted from untreated and treated cells in cold lysis buffer (50 nM Hepes at pH 7.0, $250 \mathrm{nM} \mathrm{NaCl}$ and 5 nM EDTA), and the protein concentration of the samples were determined by Bio-protein assay in 96 wells. This solution was diluted with water to $1: 4$; proteins in the cell samples were also diluted with cold PBS to 1:4. After loading $10 \mu \mathrm{l}$ of diluted protein samples into the wells and waiting for $10 \mathrm{~min}$, the developed colour was measured in all 96 wells at $600 \mathrm{~nm}$ in a spectrophotometer (Tecan Sunrise ${ }^{\mathrm{TM}}$ Absorbance Reader). Protein content was computed with the aid of a standard curve prepared using bovine serum albumin (BSA) as a standard in a concentration range of $0.02-1.34 \mu \mathrm{g} / \mathrm{ml}$.

\section{Western blot analysis}

After protein concentration was determined, $40 \mu \mathrm{g}$ samples from treated and untreated cells extracts were separated on a $10 \%$ sodium dodesyl sulfate (SDS)-polyacrylamide gel electrophoresis. The protein bands were transferred to a nitrocellulose membrane electrophoretically at $4{ }^{\circ} \mathrm{C}$ at $100 \mathrm{~V}$ for $1 \mathrm{~h}$. The membrane was blocked with $5 \%$ skimmed milk, washed 3 times with Tween 20-Tris-buffered saline (TBS-T), and transfer 
of bands was confirmed by Ponceus solution at room temperature. The first antibody against iNOS, COX-2, NFkB, TNFa, IL1 $\beta$, P38 MAPK and $\beta$-actin was added and incubated for $2 \mathrm{~h}$. After washing with TBS-T 3 times (each time for $15 \mathrm{~min}$ ), the membrane was incubated with a 1:1000 dilution of horseradish peroxidase-conjugated seconddary antibody for $1 \mathrm{~h}$ at room temperature. The membrane was again washed 3 times with TBS-T and then developed by enhanced chemi-luminescence (Amersham Life Science, Arlingon Heights, IL, U.S.A) on an xray film.

\section{Isolation of RNA from Raw 264.7 cells}

The cells $\left(3 \times 10^{6}\right.$ cells $\left./ \mathrm{ml}\right)$ were taken in culture disks and pretreated with bee venom at $0,0.5,1,2,5,10 \mu \mathrm{g} / \mathrm{ml}$ and after one $1 \mathrm{~h}$, the cells were treated with LPS $(1 \mu \mathrm{g} / \mathrm{ml})$. After $24 \mathrm{~h}$, the cells were harvested into a 1.5 $\mathrm{ml}$ Eppendorf tube using $1 \mathrm{ml}$ of Trizol reagent. The samples were homogenised and incubated for $5 \mathrm{~min}$ at room temperature to permit the complete dissociation of nucleoprotein complexes. Then, $0.2 \mathrm{ml}$ of chloroform was added and the tubes were shaken vigorously (manually) for $15 \mathrm{sec}$ and incubated for 2 to $3 \mathrm{~min}$. The samples were centrifuged at $13000 \mathrm{rpm}$ for $15 \mathrm{~min}$ at $4{ }^{\circ} \mathrm{C}$, and separated into a lower red, phenolchloroform phase, an interphase, and a colourless upper aqueous phase. The aqueous phase was transferred to a fresh tube and RNA was precipitated from the aqueous phase by mixing with $0.5 \mathrm{ml}$ isopropyl alcohol. Subsequently, $0.5 \mathrm{ml}$ of isopropyl alcohol was added and the samples were incubated at room temperature for 10 min and centrifuged at $13000 \mathrm{rpm}$ for $10 \mathrm{~min}$ at $4^{\circ} \mathrm{C}$. The supernatant was removed, the RNA pellet was washed once with $75 \%$ ethanol $(1 \mathrm{ml})$, and centrifuged at $7500 \mathrm{rpm}$ for $5 \mathrm{~min}$ at $4^{\circ} \mathrm{C}$. At the end of the procedure, the RNA pellet was briefly dried at room temperature for $5 \mathrm{~min}, 20$ ul of RNase-free water was added to it, and then incubated for $10 \mathrm{~min}$ at $56^{\circ} \mathrm{C}$. Finally, the concentration of the RNA was measured with a spectro- photometer while its quality was assessed by agarose gel electrophoresis.

\section{Reverse transcriptase polymerase chain reaction (RT-PCR)}

cDNA was synthesized from RNA isolated from cells using a SuperScript ${ }^{\mathrm{TM}}$ II kit (Invitrogen, USA). Cycle parameters were initial denaturation for $2 \mathrm{~min}$ at $95{ }^{\circ} \mathrm{C}$, annealing for $1 \mathrm{~min}$ at $57,60,60,55,60$ and $54{ }^{\circ} \mathrm{C}$ for NFKB, COX-2, iNOS, TNF $\alpha, \mathrm{IL}-1 \beta$ and GAPDH, respectively, elongation for 1 min at $72{ }^{\circ} \mathrm{C}$ and final extension for $10 \mathrm{~min}$ at $72{ }^{0} \mathrm{C}$. Primer sequence (Table 1) of the NFKB, COX-2, iNOS, TNF $\alpha, \quad I L-1 \beta$ and GAPDH (for standardization) were amplified out of each cDNA batch with 35, 30, 30, 30, 30 and 30 amplification cycle, respectively. The resulting PCR products were separated in $2 \%$ agarose gel and visualised by ethidium bromide staining.

\section{Statistical analysis}

The data are presented as mean \pm SEM. All data were analysed by one-way ANOVA and differences between the means were assessed with Duncan's multiple range tests (DMRT). Differences were considered significant at $P<0.05$. All analyses were carried out using SPSS Software ver.11.5 (Chicago, Illinois).

\section{RESULTS}

\section{Effect of bee venom on cell proliferation}

The results indicate that BV-treated cells increased proliferation up to a dose of $0.5-$ $2.0 \mu \mathrm{g} / \mathrm{ml}$. However, BV did not show any toxic effect at $5-20 \mu \mathrm{g} / \mathrm{ml}$ and the number of cells decreased more than untreated control.

\section{Effect of BV on NO production and iNOS expression}

The results (see Fig 1) indicate that NO production reduced significantly $(p<0.05)$ in a dose-dependent manner with BV treatment. 
Table 1: Primer sequences used for RT-PCR

\begin{tabular}{|c|c|c|}
\hline $\begin{array}{l}\text { Gene } \\
\text { symbol }\end{array}$ & Primer sequence $5^{\prime} \rightarrow 3^{\prime}$ & $\begin{array}{l}\text { Expected fragment } \\
\text { size (bp) }\end{array}$ \\
\hline NFkB & $\begin{array}{l}\text { 5'-GGCCTGCAAAGGTTATCGTT-3' } \\
\text { 5'-TGTCTGTGAGTTGCCGGTCTT-3' }\end{array}$ & 300 \\
\hline iNOS & $\begin{array}{l}\text { 5'-AATGGCAACATCAGGTCGGCCATCACT-3' } \\
\text { 5'-GCTGTGTGTCACAGAAGTCTCGAACTC-3' }\end{array}$ & 807 \\
\hline IL-1 $\beta$ & $\begin{array}{l}\text { 5'-TGCAGAGTTCCCCAACTGGTACATC-3' } \\
\text { 5'-GTGCTGCCTAATGTCCCCTTG AATC-3' }\end{array}$ & 387 \\
\hline TNFa & $\begin{array}{l}\text { 5'-ATGAGCACAGAAAGCATGATC-3' } \\
\text { 5'-TACAGGCTTGTCACTCGAATT-3' }\end{array}$ & 351 \\
\hline cox2 & $\begin{array}{l}\text { 5'-GGAGAGACTATCAAGATAGT-3'5'- } \\
\text { ATGGTCAGTAGACTTTTACA-3' }\end{array}$ & 721 \\
\hline GAPDH & $\begin{array}{l}\text { 5'-CCATCAACGACCCCTTCAT-3' } \\
\text { 5'- GTCCTCAGTGTAGCCCAAGA-3' }\end{array}$ & 462 \\
\hline
\end{tabular}

A
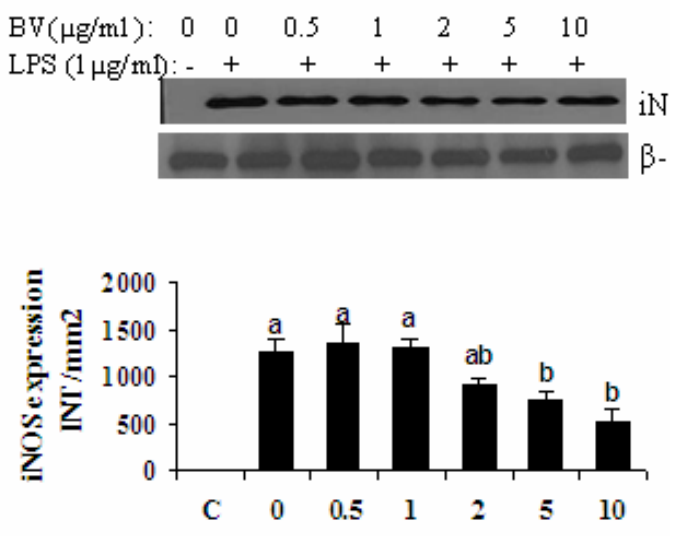

$\mathrm{C}$

BV concentration $(\mu \mathrm{g} / \mathrm{ml})$

Figure 1: The effects of bee venom on NO production and iNOS protein expression in LPS stimulated Raw 264.7 cells. Note: Values represent means \pm SEM of seven samples. Means with different superscripts $(a, b, c)$ are significantly different $(p<0.05)$.

Also, bee venom consistently inhibited the expression of iNOS protein in RAW 264.7 cells in a concentration dependent manner. These results demonstrated that bee venom produced a concentration-dependent inhibition of $\mathrm{NO}$ production and iNOS protein expression in response to LPS.

\section{Effect of BV on COX-2 expression}

The results, shown in Fig 2, indicate that bee venom at low concentrations $(0.5-2.0$ $\mu \mathrm{g} / \mathrm{ml})$ had no significant effect $(\mathrm{p}<0.05)$ on COX-2 expression, but at higher concentrations $(5-10 \mu \mathrm{g} / \mathrm{ml})$, bee venom significantly reduced COX-2 expression in the LPS-stimulated RM cells. Thus, bee venom inhibited COX-2 activity and protein expression in RAW 264.7 cells stimulated with LPS.

\section{Effect of BV on P38-MAPK and IL-1 $\beta$ expressions}

The results in Fig 3 showed that bee venom exerted a dose-dependent increase in the expression of both p38 MAPK and IL-1 $1 \beta$. The trend was similar and the rise in expressions were significant $(p<0.05)$ at doses of $5-10$ $\mu \mathrm{g} / \mathrm{ml}$ bee venom. Thus, these data established a pro-inflammatory effect of BV via p38 MAPK pathway. 


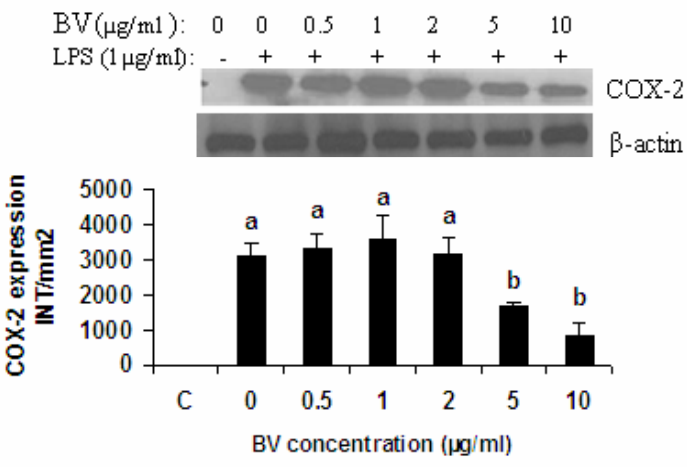

Figure 2: The effect of bee venom on COX-2 protein expression in RAW 264.7 cells. Note: Values represent the means \pm SEM of seven samples. Means with different superscripts ( $a, b$, $c)$ are significantly different $(p<0.05)$

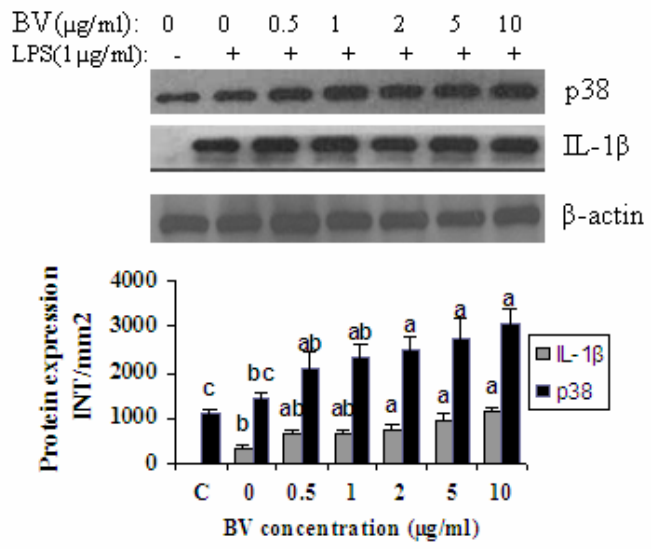

Figure 3: Effect of bee venom on P38-MAPK and IL1 $\beta$ expressions in LPS-stimulated RAW 264.7 cells. Note: Values represent the means \pm SEM of seven samples. Means with the different superscripts $(a, b, c)$ are significantly $(p<0.05)$ different.

\section{Effect of BV on NFKB activation and mRNA cytokine expression}

The results in Fig 4 and Table 2 show significant decreases in the expressions of iNOS, COX-2 and NFkB at concentrations of $2-10 \mu \mathrm{g} / \mathrm{ml}$ of bee venom in LPS-stimulated RAW cells. BV treatment also induced increased expression of IL-1 $1 \beta$ at lower concentration but the expression was significantly greater $(p<0.05)$ at higher BV concentrations $(5-10 \mu \mathrm{g} / \mathrm{ml})$. However, the effect on the expression of TNFa was not significant although expression appeared to increase in a dose-dependent.

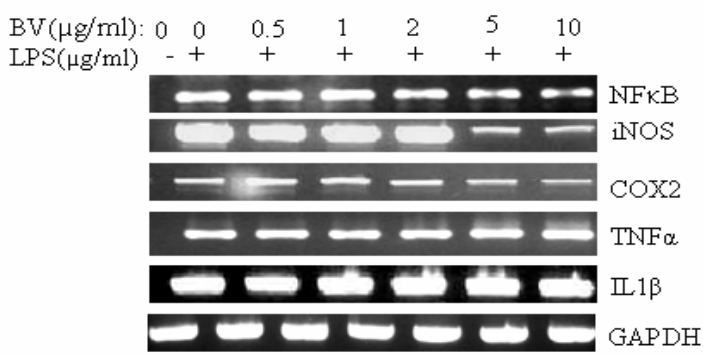

Figure 4: Effect of bee venom on NFKB activation and mRNA cytokine expression in LPS-stimulated RAW 264.7 cells $(n=3)$.

\section{DISCUSSION}

In this paper, we have presented data to show that bee venom controlled NO production in activated macrophages via the inhibition of iNOS expression, and also suppressed the expression of COX-2 acting at a transcriptional level. It is also evident from the results that bee venom inhibited LPS-induced expression of iNOS and COX2 genes through the blocking of NFKB activation at mRNA and protein expression levels. Recently, it was reported that bee venom exhibits anti-arthritic effect by reducing the expression of iNOS and COX-2 through suppression of NFkB $[3,15]$.

In this study, we observed increased activity of p38 MAPK which enhanced IL-1 $\beta$ expression in RM cells. This suggests that p38 MAPK is a critical mediator for the release of pro-inflammatory cytokines such as IL-1 $\beta$ in RM cells due to treatment with bee venom (BV).

Although BV has anti-inflammatory properties, however, it can also induce inflammation since the p38MAPK activated by several different stimuli positively regulates a variety of genes involved in inflammation, such as 
Table 2: Effect of bee venom (BV) on relative mRNA expression (mean \pm SD) of iNOS, IL-1 $\beta$, COX-2, TNF$\alpha$ and NFKB in LPS $(1 \mu \mathrm{g} / \mathrm{ml})$-stimulated RAW 264.7 cells

\begin{tabular}{|c|c|c|c|c|c|}
\hline \multirow{2}{*}{$\begin{array}{l}\text { Concentration } \\
\text { of BV }(\mu \mathrm{g} / \mathrm{ml})\end{array}$} & \multicolumn{5}{|c|}{ Bee venom } \\
\hline & $\begin{array}{c}\text { iNOS } \\
\text { (INT/mm2) }\end{array}$ & $\begin{array}{c}\text { IL-1 } \\
\text { (INT/mm2) }\end{array}$ & $\begin{array}{c}\text { COX2 } \\
\text { (INT/mm2) }\end{array}$ & $\begin{array}{c}\text { TNFa } \\
\text { (INT/mm2) }\end{array}$ & $\begin{array}{c}\text { NFkB } \\
\text { (INT/mm2) }\end{array}$ \\
\hline 0 & $\begin{array}{l}7.37 \times 10^{3} \\
\pm 542.2^{\mathrm{a}}\end{array}$ & $\begin{array}{c}5.39 \times 10^{3} \\
\pm 403^{\mathrm{b}}\end{array}$ & $\begin{array}{l}2.23 \times 10^{3} \\
\pm 256.8^{\mathrm{a}}\end{array}$ & $\begin{array}{l}3.99 \times 10^{3} \\
\pm 81.5^{\mathrm{a}}\end{array}$ & $\begin{array}{c}3.94 \times 10^{3} \\
\pm 216^{\mathrm{a}}\end{array}$ \\
\hline 0.5 & $\begin{array}{l}6.31 \times 10^{3} \\
\pm 528.9^{\mathrm{ab}}\end{array}$ & $\begin{array}{l}5.90 \times 10^{3} \\
\pm 446.3^{\mathrm{ab}}\end{array}$ & $\begin{array}{l}2.39 \times 10^{3} \\
\pm 223.8^{a}\end{array}$ & $\begin{array}{r}4.08 \times 10^{3} \\
\pm 82.3^{\mathrm{a}}\end{array}$ & $\begin{array}{c}4.11 \times 10^{3} \\
\pm 259^{\mathrm{a}}\end{array}$ \\
\hline 1 & $\begin{array}{l}6.19 \times 10^{3} \\
\pm 324.1^{\mathrm{ab}}\end{array}$ & $\begin{array}{r}6.12 \times 10^{3} \\
\pm 360.4^{\mathrm{ab}}\end{array}$ & $\begin{array}{l}2.56 \times 10^{3} \\
\pm 165.6^{a}\end{array}$ & $\begin{array}{l}4.08 \times 10^{3} \\
\pm 82^{\mathrm{a}}\end{array}$ & $\begin{array}{c}4.08 \times 10^{3} \\
\pm 237^{a}\end{array}$ \\
\hline 2 & $\begin{array}{l}6.06 \times 10^{3} \\
\pm 366.5^{b}\end{array}$ & $\begin{array}{l}6.45 \times 10^{3} \\
\pm 305^{\mathrm{ab}}\end{array}$ & $\begin{array}{r}2.53 \times 10^{3} \\
\pm 299.3^{\mathrm{a}}\end{array}$ & $\begin{array}{c}4.20 \times 10^{3} \\
\pm 30.2^{\mathrm{a}}\end{array}$ & $\begin{array}{c}3.73 \times 10^{3} \\
\pm 172^{\mathrm{ab}}\end{array}$ \\
\hline 5 & $\begin{array}{c}1.09 \times 10^{3} \\
\pm 77.7^{\mathrm{c}}\end{array}$ & $\begin{array}{l}6.81 \times 10^{3} \\
\pm 366.5^{\mathrm{a}}\end{array}$ & $\begin{array}{l}1.36 \times 10^{3} \\
\pm 291.6^{b}\end{array}$ & $\begin{array}{c}4.24 \times 10^{3} \\
\pm 90.6^{\mathrm{a}}\end{array}$ & $\begin{array}{c}3.03 \times 10^{3} \\
\pm 197^{\mathrm{b}}\end{array}$ \\
\hline 10 & $\begin{array}{l}0.83 \times 10^{3} \\
\pm 86^{\mathrm{c}}\end{array}$ & $\begin{array}{l}6.92 \times 10^{3} \\
\pm 469.4^{\mathrm{a}}\end{array}$ & $\begin{array}{l}1.07 \times 10^{3} \\
\pm 181.2^{b}\end{array}$ & $\begin{array}{c}4.48 \times 10^{3} \\
\pm 161^{\mathrm{a}}\end{array}$ & $\begin{array}{c}1.96 \times 10^{3} \\
\pm 290^{\mathrm{c}}\end{array}$ \\
\hline
\end{tabular}

$a, b, c:$ means with different superscripts are significantly different $(p<0.05)$.

TNF- $\alpha$ and IL-1 $\beta[20,22]$. These cytokines appear to be interlinked in a cascade, being produced serially by cells during an inflammatory response. Cumulative evidence indicates that an abnormality in the production or functions of TNFa and IL-1 $\beta$ play a role in many inflammatory lesions [23]. Bee venom induced an increase in the activity of p38MAPK which activated IL-1 $\beta$ expression at protein and mRNA levels

iNOS, TNF $\alpha$, COX2 and IL-1 $1 \beta$. Therefore, inhibitors of NFKB activation are important in anti-inflammatory activity. Our data show that bee venom can directly inhibit NFKB activation and suppress the expression of iNOS and COX2. Although bee venom inhibited NFKB activation, it also increased the activation of TNF $\alpha$ and IL-1 $\beta$ mRNA expression. The naturally occurring peptides of whole bee venom have various pharmacological potencies to produce local inflammation, nociception and pain hypersensitivity in mammals. Over $50 \%$ of whole bee venom plays a central role in the production of local inflammation [24]; however, these components exhibit antiinflammatory activity in inflammatory cells.

\section{CONCLUSION}

NFKB and p38 MAPK signal pathways are involved in triggering the functional activation of LPS-stimulated macrophage and play an important role in the release of proinflammatory and anti-inflammatory cytokines. We suggest that some components of bee venom can induce inflammation by inducing IL- $1 \beta$ via p38 MAPK but some other components act as antiinflammatory by suppressing iNOS and COX2 via NFKB when there is already inflammation. Further study is required to confirm the activity of individual components of bee venom at cellular and molecular level.

\section{ACKNOWLEDGEMENT}

The authors wish to thank Chung-Jin Biotech Co Ltd for supplying samples of Korean bee venom, and Oliver Abanto, for helpful discussions throughout the course of this work.

\section{REFERENCES}

1. Sumikura $H$, Anderson $O K$, Drewes AW, ArendtNelsen LA. A comparision of hyperalgesia and 
neurogenic inflammation induced by melittin and capsaicin in humans. Neurosci Lett., 2003; 337: 147-150.

2. Nam KW, Je KH, Lee JH, Kang SK, Mar W. Inhibition of COX-2 activity and proinflammatory cytokines (TNF-alpha and IL-1beta) production by water soluble sub-fractionated parts from bee (Apis melifera) venom. Archiv Pharmacol Res., 2003; 26: 383-388.

3. Park HJ, Lee $S H$, Son DJ, Oh KW, Kim KH, Song S, Kim GJ, Oh GT, Yoon DY, Tae Hong JT. Antiarthritic effect of bee venom: inhibition of inflammation mediator generation by suppression of NF-kB through interaction with the p50 subunit. Arthritis Rheumatism, 2004; 50: 3504-3515

4. Jang HS, Kim SK, Han JB, Ahn HJ, Bae H, Min BI. Effects of bee venom on the pro-inflammatory responses in RAW264.7 macrophage cell line. J Ethnopharmacol, 2005; 99: 157-160.

5. Amin MA, Abdel-Raheem IT, Madkor HR. Wound healing and anti-inflammatory activities of bee venom-chitosan blend films. J Drug Delivery Sci Technol., 2008; 18:424-430.

6. Yoon SY, Kwon YB, Kim HW, Roh DH, Seo HS, Han $H J$, Lee HJ, Lee JH. Bee venom injection produces a peripheral anti-inflammatory effect by activation of a nitric oxide-dependent spinocoeruleus pathway. Neurosci Lett., 2008; 430: 163-168.

7. Chen J, Chen HS. Pivotal role of capsaicin-sensitive primary afferents in development of both heat and mechanical hyperalgesia induced by intraplantar bee venom injection. Pain, 2001; 91: 367-376.

8. Lariviere WR, Wilson SG, Laughlin TM, Kokayeff A, West EE, Adhikari SM, Wan Y, Mogil JS. Heritability of nociception. III. Genetic relationships among commonly used assays of nociception and hypersensitivity. Pain, 2002; 97: 75-86.

9. Chen J. The bee venom test: a novel useful animal model for study of spinal coding and processing of pathological pain information. In: Chen J, Chen C, Han JS, Willis WD, eds., Experimental pathological pain: from molecules to brain function. Beijing, Science Press, 2003; pp 77-110.

10. Billingham ME, Morley J, Hanson JM, Shipolini RA, Vernon CA Letter: An anti-inflammatory peptide from bee venom. Nature, 1973; 245: 163-164.

11. Habermann E. Chemistry, pharmacology and toxicology of bee, wasp and hornet venoms. In: Bucherl W, Buckley EE Eds., Venomous Animals and Their Toxins: Venomous Invertebrates, Vol. III, New York, Academic Press, 1971; pp 61-93.
12. Banks BEC, Shipolini RA. Chemistry and pharmacology of honeybee venom. In: Piek T Ed., Venoms of the Hymenoptera. Academic Press, London, 1986; pp 329-416

13. Lee JH, Kwon YB, Han HJ, Mar WC, Lee H., Yang IS, Beitz AJ, Kang SK. Bee venom pretreatment has both an antinociceptive and anti-inflammatory effect on carrageenaninduced inflammation. J Vet Med Sci, 2001; 63: 251-259.

14. Higgs GA, Moncada S, Vane JR. Eicosanoids in inflammation. Annal Clin Res., 1984; 16, 287299.

15. Roman-Blas JA, Jimenez SA. NFkappaB as a potential therapeutic target in osteoarthritis and rheumatoid arthritis. Osteoarthritis Cartilage, 2006; 14: 839-848.

16. Suh N, Honda T, Finlay HJ, Barchowsky A, Williams C, Benoit NE, Xie QW, Nathan C, Gribble GW, Sporn MB. Novel Triterpenoids suppress inducible nitric oxide synthase (iNOS) and inducible cyclooxygenase (COX-2) in mouse macrophages. Cancer Res., 1998; 58: 717723.

17. Baldwin AS. Series introduction: The transcription factor NF kappa $B$ and human disease. J Clin Invest., 2001; 107: 3-6.

18. Beutler B, Cerami A. The biology of cachectin/TNFa primary mediator of the host response. Annual Rev Immuno.I, 1989; 7: 625-655.

19. West MA, LI MH, Seatter SC, Bubrick MP. Preexposure to hypoxia or septic stimuli differentially regulates endotoxin release of tumor necrosis factor, interleukin-6, interleukin1, prostaglandin E2, nitric oxide, and superoxide by macrophages. J Trauma, 1994; 37: 82-89.

20. Chen $B C$, Chen $Y H$, Lin WW. Involvement of $p 38$ mitogen-activated protein kinase in lipopolysaccharide-induced iNOS and COX-2 expression in $\mathbf{J 7 7 4}$ macrophages. Immunol., 1999; 97: 124-129.

21. Lee JC, Kumar S, Griswold DE, Underwood DC, Votta BJ, Adams JL. Inhibition of p38 MAP kinase as a therapeutic strategy. Immunopharmacol., 2000; 47; 185-201.

22. Ono $K$, Han J. The p38 signal transduction pathway: activation and function. Cell Signalling, 2000; 12: 1-13.

23. De Nardin E. The role of inflammatory and immunological mediators in periodontitis and cardiovascular disease. Annal Periodontol., 2001; 6: 30-40.

24. Chen YN, Li KC, Li GW, Shang D, Liu NZ, Lu M, Zhang JW, Jl YH, Gao GD, Chen J. Pain hypersensitivity in mammals, and among the five identified reverse-phase high pressure liquid chromatography. Neurosci., 2005; 138: 631-640. 